\title{
Crabeater seal diving behaviour in eastern Antarctica
}

\author{
Stephen M. Wall ${ }^{1, *}$, Corey J. A. Bradshaw ${ }^{2}$, Colin J. Southwell ${ }^{3}$, Nicholas J. Gales ${ }^{3}$, \\ Mark A. Hindell ${ }^{1}$
}

${ }^{1}$ Antarctic Wildlife Research Unit, School of Zoology, University of Tasmania, Private Bag 05, Hobart, Tasmania 7001, Australia ${ }^{2}$ School for Environmental Research, Institute of Advanced Studies, Charles Darwin University, Darwin, Northern Territory 0909, Australia

${ }^{3}$ Australian Antarctic Division, Department of the Environment and Heritage, 203 Channel Highway, Kingston, Tasmania 7050, Australia

\begin{abstract}
Southern Ocean waters are highly productive and contain important food resources for many indigenous predators, including humans. Management of these resources has fallen under the regulation of the Convention for the Conservation of Antarctic Marine Living Resources (CCAMLR), which has identified a suite of predators as indicator species for monitoring ecosystem fluctuations, including crabeater seals. For crabeater seals to fulfil this role, however, they must respond predictably to fluctuations in krill distribution and abundance. Here, we investigated the validity of using the diving behaviour of this species as an indicator of krill distribution and abundance. We used behavioural data collected from 23 crabeater seals fitted with satellite-linked timedepth recorders off eastern Antarctica to quantify habitat use as a function of the amount of time they spent within geographic regions with varying environmental characteristics. This was then linked with diving behaviour in those regions. By integrating geographic location and diving parameters, we demonstrated that habitat use and foraging behaviour within eastern Antarctic waters fluctuated in response to seasonal and spatial environmental variability. Our attempts to use oceanographic variables to develop models of crabeater seal habitat use and behaviour demonstrated real limitations in inferring behaviour from a simple set of environmental factors, but we identified ocean depth and the proximity to the ice edge as factors influencing seasonal habitat use and diving behaviour. Whilst our understanding of the influences driving crabeater seal distribution has improved as a result of telemetry studies, it would appear premature to infer cross-species patterns in distribution and abundance with krill given the low predictive power of models derived in the present study. Furthermore, the dynamic and regionally variable use of pelagic habitat by this widely abundant Antarctic predator has important implications for the estimation of crabeater seal biomass.
\end{abstract}

KEY WORDS: Southern Ocean $\cdot$ Crabeater seal $\cdot$ Krill $\cdot$ Diving behaviour $\cdot$ Habitat use $\cdot$ Satellite telemetry $\cdot$ Generalised linear models

\section{INTRODUCTION}

The Southern Ocean comprises approximately $10 \%$ of the world's oceans and is unique in its physical and biological diversity. Characterised environmentally as highly variable and dynamic (Constable et al. 2003), it has low biological diversity, with most species only 2 to 3 trophic levels from primary production (Alonzo et al.
2003). Nevertheless, overall biomass is considerable, with species such as Antarctic krill Euphausia superba forming a key resource for many top-level predators within the Southern Ocean (Croxall et al. 1999). Under the Convention for the Conservation of Antarctic Marine Living Resources' (CCAMLR) Ecosystem Monitoring Program (CEMP), a number of key predators were nominated as indicator species for the krill-based 
ecosystem, including the crabeater seal Lobodon carcinophaga. Current estimates suggest that crabeater seals consume around 60 to 70 million tonnes of krill per year (Riedman 1990), based on global population estimates of 10 to 15 million seals (Shaughnessy 1999, Bengston 2002), effectively making the species the single largest consumer of krill in the world (Hewitt \& Lipsky 2002). CCAMLR proposed a suite of parameters measured from predators for their potential to reflect prey availability and respond to environmental change: (1) reproduction, (2) growth and condition, (3) foraging ecology and behaviour, and (4) abundance and distribution (Agnew 1997). However, such information is limited for Southern Ocean predators in general, particularly for crabeater seals that use the remote and inaccessible pack ice.

The use of predators as indicators for ecosystem processes requires an as yet incomplete understanding of the factors influencing the relationships between prey availability, predators and the environment (Hindell et al. 2003). The underlying premise in developing proxies for species distribution and abundance using alternate indicator taxa relies on the assumption that the inherent relationships between species in a specific environmental context will reflect environmental variability and change equally. In other words, we should expect that a measurable effect in one species to some perturbation will also be measurable in another linked species within that same environment. There is some evidence for such relationships in the breeding success and distribution of higher-order predators in years with poor prey availability (McCafferty et al. 1998, Croxall et al. 1999, Clarke et al. 2002, Lynnes et al. 2004). The response might be distributional, demographical, or behavioural, and may be positive or negative (Hindell et al. 2003). Regardless, the implication gives direction for studies to link species parameters that are difficult to measure or quantify (e.g. krill distribution and abundance) with parameters that are more readily measurable (e.g. predator foraging behaviour). Furthermore, by determining a relationship between behaviour and habitat, we create an environmental reference for predictive modelling. In this study we attempt to quantify diving behaviour by crabeater seals as a function of spatial and temporal environmental variability. This novel approach is consistent with and has the potential to enhance management by allowing inferences to be made between crabeater seal diving characteristics, environmental variability and potential krill distribution and behaviour.

The inherent difficulty in marrying different taxonomic groups together with corresponding environmental correlates is having sufficient spatial and temporal overlap in the datasets to enable relationships to be modelled. This is particularly true with 2 widely dis- tributed and inaccessible species such as crabeater seals and krill. The recent international Antarctic Pack-Ice Seal (APIS) program focused on quantifying the role of pack-ice seals in the Southern Ocean (APIS 1996). A component of the Australian Antarctic Division's (AAD) involvement in the program involved deploying satellite-linked time-depth recorders (SLTDRs) on a sample of seals to estimate the haul-out probability (Southwell 2005). The data obtained from these SLTDRs included not only haul-out status but diving behaviour and location. These latter data provided the opportunity to investigate crabeater seal behaviour as a function of varying environmental conditions, with a view to understanding crabeater seal habitat use better. If a set of predictive models could be derived to predict seal behaviour based on postulated environmental correlates, then future studies linking seal behaviour with that of krill may provide a mechanism for krill distribution to be inferred and mapped.

\section{MATERIALS AND METHODS}

Behavioural data. Data on diving behaviour, location, time of day and date were obtained from SLTDRs (Wildlife Computers) attached to 23 adult crabeater seals (17 males, 6 females) captured between September and December each year from 1994 to 1999 (Table 1). This work was conducted under permits 94/01，95/01，95/02，96/02，97/01，98/03 and 99/02 under the Antarctic Treaty (Environment Protection) Act 1980, and Antarctic Seals Conservation Regulations.

The satellite tags were programmed to transmit every $45 \mathrm{~s}$ when wet and every $90 \mathrm{~s}$ when dry. Geographical position at each transmission was derived using the Argos System (Service Argos 1996), with date and time (Greenwich Mean Time: GMT) corrected to local time based on the seal's geographic position (local solar time $=$ GMT + degrees longitude/15) (Burns et al. 2004). The SLTDRs stored sum-

Table 1. Lobodon carcinophaga. Maximum upper limits for each dive parameter bin used to program satellite tags

\begin{tabular}{|lll|}
\hline Year & Data & Upper bin limits \\
\hline \multirow{2}{*}{1994} & Dives per depth bin & $20,40,80,160,320,>320(\mathrm{~m})$ \\
& Dives per time bin & $1,2,4,8,16,>16(\mathrm{~min})$ \\
& Time per depth bin & Not recorded \\
$1995-99$ & Dives per depth bin & $10,20,30,40,50,60,70,80$, \\
& & $90,100,150,200,250,>250(\mathrm{~m})$ \\
& Dives per time bin & $1,2,3,4,5,6,7,8,9,10,11$, \\
& & $12,13,>13(\mathrm{~min})$ \\
& Time per depth bin & $0,4,10,20,30,40,50,60,70$, \\
& & $80,90,100,150,>150(\mathrm{~m})$ \\
\hline
\end{tabular}


mary information on maximum dive depths, dive durations and the amount of time spent at certain depths (time-at-depth) into a set of bins with user-defined limits. Each bin contained counts for the number of dives falling within its defined range accumulated over a period of $6 \mathrm{~h}$. Time-at-depth bins record a proportional count within each bin for each 6 -h period, thereby allowing the amount of time within each depth bin to be calculated (Wildlife Computers 1995). Bin definition was revised following the first year of the study (Table 2), making some aspects of the information on diving behaviour incompatible. This occurred because of an update in satellite tags and software in the later years. All tags recorded dive depths with a resolution of $2 \mathrm{~m}$ to a maximum depth of $500 \mathrm{~m}$. The number of dives in each depth and duration bin was recorded over all years; however, time-at-depth was only recorded from 1995. The minimum depth to be considered a dive was set at $8 \mathrm{~m}$ during 1994 and $4 \mathrm{~m}$ thereafter.

Dive behaviour was recorded and stored in 6-h blocks $(13.00$ to $18.59 .59,19.00$ to $00.59 .59,01: 00$ to 06.59.59, and 07.00 to $12.59 .59 \mathrm{~h} \mathrm{GMT)}$ for each 24 -h period, along with the date, time and geographical location. Dive depth, dive duration, time-at-depth and dive frequency were used directly as behavioural parameters for analysis with environmental data. A fifth behavioural parameter, time spent in a geograph-

Table 2. Lobodon carcinophaga. Capture date, satellite transmission days, capture location and sex of the 23 tracked crabeater seals

\begin{tabular}{|lcccc|}
\hline \multirow{2}{*}{$\begin{array}{l}\text { Capture } \\
\text { date (d/mo/yr) }\end{array}$} & $\begin{array}{c}\text { Transmission } \\
\text { duration (d) }\end{array}$ & \multicolumn{2}{c}{ Location } & \multirow{2}{*}{ Lex } \\
\hline $18 / 09 / 1994$ & 56 & $61^{\circ} 24^{\prime} \mathrm{S}$ & $78^{\circ} 22^{\prime} \mathrm{E}$ & $\mathrm{M}$ \\
$20 / 09 / 1994$ & 91 & $63^{\circ} 23^{\prime} \mathrm{S}$ & $74^{\circ} 58^{\prime} \mathrm{E}$ & $\mathrm{M}$ \\
$20 / 09 / 1994$ & 42 & $63^{\circ} 20^{\prime} \mathrm{S}$ & $75^{\circ} 32^{\prime} \mathrm{E}$ & $\mathrm{F}$ \\
$22 / 09 / 1994$ & 56 & $63^{\circ} 23^{\prime} \mathrm{S}$ & $74^{\circ} 58^{\prime} \mathrm{E}$ & $\mathrm{M}$ \\
$30 / 09 / 1995$ & 54 & $62^{\circ} 34^{\prime} \mathrm{S}$ & $98^{\circ} 03^{\prime} \mathrm{E}$ & $\mathrm{M}$ \\
$02 / 10 / 1995$ & 88 & $62^{\circ} 43^{\prime} \mathrm{S}$ & $88^{\circ} 07^{\prime} \mathrm{E}$ & $\mathrm{M}$ \\
$15 / 10 / 1996$ & 85 & $62^{\circ} 53^{\prime} \mathrm{S}$ & $93^{\circ} 01^{\prime} \mathrm{E}$ & $\mathrm{M}$ \\
$16 / 10 / 1996$ & 84 & $62^{\circ} 27^{\prime} \mathrm{S}$ & $88^{\circ} 08^{\prime} \mathrm{E}$ & $\mathrm{M}$ \\
$16 / 10 / 1996$ & 75 & $62^{\circ} 29^{\prime} \mathrm{S}$ & $88^{\circ} 04^{\prime} \mathrm{E}$ & $\mathrm{F}$ \\
$18 / 10 / 1996$ & 52 & $62^{\circ} 09^{\prime} \mathrm{S}$ & $85^{\circ} 21^{\prime} \mathrm{E}$ & $\mathrm{F}$ \\
$25 / 10 / 1996$ & 81 & $65^{\circ} 27^{\prime} \mathrm{S}$ & $75^{\circ} 35^{\prime} \mathrm{E}$ & $\mathrm{M}$ \\
$10 / 10 / 1997$ & 85 & $62^{\circ} 10^{\prime} \mathrm{S}$ & $101^{\circ} 46^{\prime} \mathrm{E}$ & $\mathrm{M}$ \\
$10 / 10 / 1997$ & 55 & $62^{\circ} 10^{\prime} \mathrm{S}$ & $101^{\circ} 46^{\prime} \mathrm{E}$ & $\mathrm{F}$ \\
$12 / 10 / 1997$ & 80 & $62^{\circ} 34^{\prime} \mathrm{S}$ & $88^{\circ} 56^{\prime} \mathrm{E}$ & $\mathrm{M}$ \\
$13 / 10 / 1997$ & 82 & $62^{\circ} 22^{\prime} \mathrm{S}$ & $83^{\circ} 05^{\prime} \mathrm{E}$ & $\mathrm{M}$ \\
$13 / 10 / 1997$ & 38 & $62^{\circ} 22^{\prime} \mathrm{S}$ & $83^{\circ} 05^{\prime} \mathrm{E}$ & $\mathrm{M}$ \\
$15 / 10 / 1997$ & 49 & $62^{\circ} 40^{\prime} \mathrm{S}$ & $71^{\circ} 55^{\prime} \mathrm{E}$ & $\mathrm{F}$ \\
$16 / 10 / 1997$ & 40 & $62^{\circ} 42^{\prime} \mathrm{S}$ & $67^{\circ} 55^{\prime} \mathrm{E}$ & $\mathrm{F}$ \\
$19 / 10 / 1997$ & 43 & $63^{\circ} 11^{\prime} \mathrm{S}$ & $67^{\circ} 46^{\prime} \mathrm{E}$ & $\mathrm{M}$ \\
$09 / 11 / 1998$ & 57 & $64^{\circ} 31^{\prime} \mathrm{S}$ & $108^{\circ} 24^{\prime} \mathrm{E}$ & $\mathrm{M}$ \\
$16 / 11 / 1998$ & 49 & $65^{\circ} 31^{\prime} \mathrm{S}$ & $78^{\circ} 48^{\prime} \mathrm{E}$ & $\mathrm{M}$ \\
$08 / 12 / 1999$ & 35 & $64^{\circ} 41^{\prime} \mathrm{S}$ & $141^{\circ} 15^{\prime} \mathrm{E}$ & $\mathrm{M}$ \\
$15 / 12 / 1999$ & 30 & $64^{\circ} 30^{\prime} \mathrm{S}$ & $117^{\circ} 40^{\prime} \mathrm{E}$ & $\mathrm{M}$ \\
\hline
\end{tabular}

ical or spatial unit, was derived from location data received from the SLTDRs. We used Interactive Data Language (IDL 5.0, Research Systems) code developed for southern elephant seals (Bradshaw et al. 2002) to filter locations and remove data points that would require an unrealistic rate of travel (Vincent et al. 2002). An estimated maximum rate of travel for crabeater seals was set at $4 \mathrm{~m} \mathrm{~s}^{-1}$ (Thompson et al. 1993, Burns et al. 2004). IDL produced 2 key datasets: a $25 \times$ $25 \mathrm{~km}$ raster grid encompassing all filtered seal tracks (Fig. 1a), and the location and putative crossing times for the entry and exit points for each grid cell along each seal's track, from which grid cell occupancy time was interpolated assuming a constant rate of travel between successive locations (Bradshaw et al. 2002). A spatial resolution of $25 \times 25 \mathrm{~km}$ was based on the minimum resolution of the ice data (see below).

Because the SLTDRs summarised behavioural data in bins for each 6-h period and stored data for up to $24 \mathrm{~h}$ prior to transmission, behavioural data were temporally divorced from location data (recorded at the time of transmission). To overcome this restriction we partitioned dive behaviours within each 6 -h block into their corresponding grid cells. Each 6 -h block of diving behaviour (i.e. count data for behavioural histogram bins) was aligned chronologically with the grid cell entry and exit times for a particular seal, and assuming a constant rate of travel the proportional amount of each 6-h time block was calculated for each grid cell. Using this time proportion, each diving parameter within a given 6 -h block was partitioned proportionately into the corresponding grid cell, thereby linking the behavioural data with the spatial data.

Environmental data. Direct investigation of the relationships between seal behaviour and biological data from lower trophic levels (e.g. krill and primary producers) was not possible. We instead used physical data (ice and bathymetry) as likely proxies for biological variability. Weekly ice concentration and ice extent data were obtained from 2 datasets: the Navy/NOAA Joint Ice Centre (JIC) (Sept 1994 to Oct 1997), and the National Ice Centre (NIC) (Oct 1997 to Jan 2000). Both sources were derived from a combination of satellite imagery from the Advanced Very High Resolution Radiometer (AVHRR) and Special Sensor Microwave/ Imager $(\mathrm{SSM} / \mathrm{I})$. Ice data were gridded at a resolution of $25 \times 25 \mathrm{~km}$ and represent sea ice concentrations ranging from 0 to $100 \%(<15 \%$ cover was classified as open water), categorised in $5 \%$ increments.

Bathymetry data were extracted from the ETOPO2 dataset (NOAA National Geophysical Data Centre 2001), which is a digital database of land and sea floor elevations on a 2-min latitude/longitude grid. The ETOPO2 dataset includes a bathymetric map of the oceans with a horizontal resolution of 1 to $12 \mathrm{~km}$ 

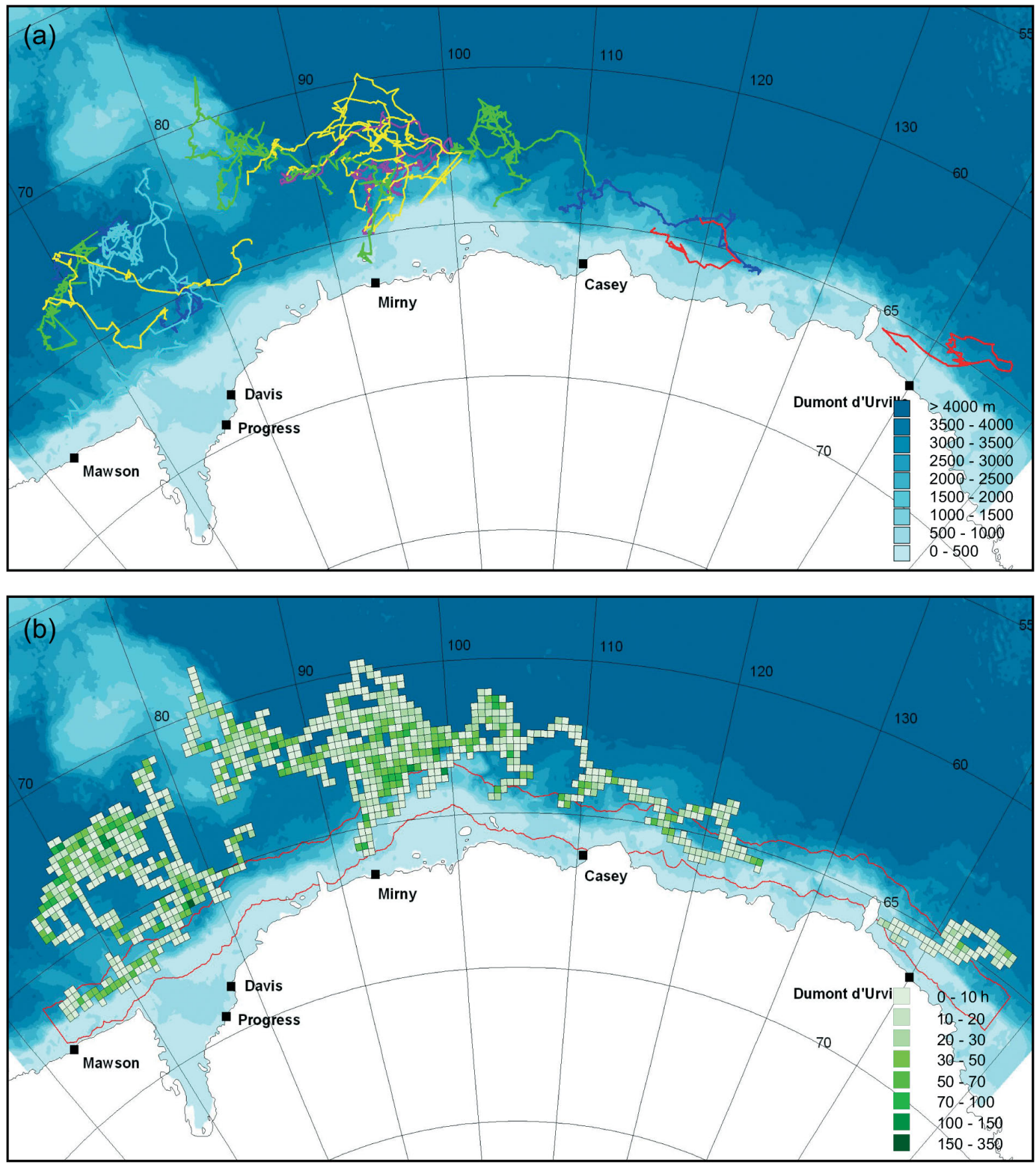

Fig. 1. Lobodon carcinophaga. (a) The study area defined by the limits of crabeater seal movements. Tracks include all 23 crabeater seals tracked over the $5 \mathrm{yr}$ period of the AAD APIS program. Track colours delineate the years individual seals were tracked: 1994 = light blue, 1995 = purple, 1996 = yellow, $1997=$ green, $1998=$ dark blue, $1999=$ red. (b) Total time spent by all seals within all $25 \times 25 \mathrm{~km}$ grid cells which encapsulate all of the seal tracks over the study. Red lines identify the boundaries of the $75 \mathrm{~km}$ buffer north and south of the shelf break, defined by the $1000 \mathrm{~m}$ isobath

derived by combining satellite altimetry observations, shipboard echo-sounding measurements and high resolution marine gravity information from the Geosat and ERS-1 satellites (Smith \& Sandwell 1997). Ocean floor gradient was derived from the ETOPO2 dataset.
Raster grids were defined for each seal and for each week that the seals were tracked to determine occupancy times associated with weekly ice concentrations and locations in relation to the ice edge. Five environmental variables were extracted or derived by inter- 
rogating each of the base data layers within each spatial grid: ocean depth, ocean floor gradient, distance from the ice edge, distance from the shelf break and percentage ice cover. For ocean depth and ocean floor gradient, the average value was calculated within each $25 \times 25 \mathrm{~km}$ grid cell. A weighted average ice concentration was ascribed to each weekly grid cell based on the proportion of each ice concentration category occurring in the grid cell for that week. The distance to the ice edge was the straight-line distance to the closest open water/ice edge point from the centre of each grid cell, where open water was classified as less than $15 \%$ ice cover. Likewise, the distance to the shelf break was calculated as the straight-line distance to the closest point measured from the centre of the grid cell. The shelf break was defined as the $1000 \mathrm{~m}$ isobath from the bathymetric data.

Analysis. Interannual variability was not included as a factor in our analyses because (1) seal numbers were not evenly distributed over all years, with a minimum of 2 in 1995, 1998 and 1999, and a maximum of 8 in 1997, and (2) yearly ice limitations and shipping schedules influenced the capture locations of seals which potentially biased spatial conclusions that could be derived for particular years. However, inter-annual variability was captured in the derivation of the sea ice data. Potential gender and seasonal differences in habitat use and diving behaviour were examined using ANOVA (Sokal \& Rohlf 1995). Seasons were defined based on the reproductive behaviour of crabeater seals (Southwell et al. 2003), where grid cell records were classified as either pre-breeding (before 4 October), breeding (4 October to 16 November) or post-breeding (after 16 November). The levels of correlation between the 5 environmental variables within each season were examined using Spearman's coefficient of rank correlation (Sokal \& Rohlf 1995). Frequency histograms of the 5 environmental variables were plotted to visualise seasonal differences in habitat use (see 'Results'). Differences in frequency distributions were tested for significance using a series of $G$ tests for independence with a William's correction factor $(q)$ to reduce the observed value of $G$ for small sample sizes (Sokal \& Rohlf 1995). In addition, a conservative critical significance level of $p=0.01$ was used for assessing $G$-tests.

The seal diving parameters dive depth, dive duration and time-at-depth were all strongly correlated (depth and duration, Spearman's $\mathrm{r}_{\mathrm{S}}=0.79, \mathrm{n}=684, \mathrm{p}>0.001$; depth and time-at-depth, Spearman's $\mathrm{r}_{\mathrm{S}}=0.73, \mathrm{n}=685$, $\mathrm{p}>0.001$; duration and time-at-depth, Spearman's $\mathrm{r}_{\mathrm{S}}=$ $0.65, \mathrm{n}=690, \mathrm{p}>0.001$ ), and model-selection algorithms identified dive depth as the strongest of the 3 parameters; therefore, dive duration and time-at-depth were not considered further in our analysis. However, dive frequency was included as a separate parameter, which we took as a measure of foraging effort we believed was not clearly evident in the other diving parameters.

Location and diving behaviours were partitioned either into the breeding or post-breeding seasons accordingly. The pre-breeding season data were not included in the analysis due to (1) the number of location records were insufficient for modelling, and (2) only the 1995 to 1999 data could be used in the behavioural analysis and these did not cover the pre-breeding season. Patterns in behaviour were investigated seasonally, and diurnally within seasons. Only the two 6-hour blocks that corresponded with midnight and midday (21.00 to 03.00 and 09.00 to $15: 00 \mathrm{~h}$ local time) were used for the diurnal pattern analysis. This removed biases associated with variable daylight hours. The geographical location of seals may also have affected diving behaviour; therefore, we investigated differences in dive parameters over and off the shelf break. For this analysis the shelf break area was classified as an area $75 \mathrm{~km}$ north and south of the $1000 \mathrm{~m}$ isobath. To determine if spatial, seasonal and/or diurnal patterns were influencing dive behaviours, a series of randomised (rand.) $\chi^{2}$ tests (Roff \& Bentzen 1989) were applied to frequencies of occurrences within discrete histogram bins. A randomised approach was used to overcome the low counts in some histogram categories of diving behaviour.

A series of generalised linear models (GLMs) (McCullagh \& Nelder 1989) were constructed using the R Package (R Development Core Team 2004) to examine the possible linear relationships between behavioural parameters (time spent per grid cell, dive depth and dive frequency) and the environmental variables. We used full-subsets regression to identify an a priori model set including combinations of each of the environmental correlates hypothesised to influence the response variable (ocean depth, ocean floor gradient, ice concentration, distance to ice edge and distance to the shelf break). The dataset was randomly sampled to remove $20 \%$ of the data prior to model generation to reduce the likelihood of spatial autocorrelation. Examination of the residuals for all models determined the statistical error distribution (i.e. Gaussian, gamma etc.) and the link function most appropriate for each analysis; here we used a gamma distribution with a log link function. Model selection was based on Akaike's Information Criteria corrected for small samples (AIC $\mathrm{C}_{\mathrm{c}}$ ) (Lebreton et al. 1992, Burnham \& Anderson 2002). $\mathrm{AIC}_{\mathrm{C}}$ values were ranked, with the most parsimonious model(s) having the lowest $\mathrm{AIC}_{\mathrm{c}}$ values and highest model weights (Lebreton et al. 1992). The weights of evidence $\left(W+_{i}\right)$ for each predictor were calculated by summing the model $\mathrm{AIC}_{\mathrm{C}}$ weights $\left(w_{i}\right)$ over all models 
in which each term appeared. Because $W+_{i}$ values were relative rather than absolute, a baseline for comparing relative $\mathrm{Wt}_{i}$ values across predictors was required. Following Burnham \& Anderson (2002), we randomised the data for each predictor separately within the dataset, re-calculated $w+_{i}$, and repeated this procedure 100 times for each predictor. The median of this new randomized $w+_{i}$ distribution for each predictor was taken as the baseline (null) value $\left(w+_{0}\right)$. For each term the absolute weight of evidence $(\Delta w+)$ was obtained by subtracting $w+_{0}$ from $w+_{i}$. Predictors with $\Delta w+$ of zero or less have essentially no explanatory power.

\section{RESULTS}

Throughout the study, tracked seals occupied 1859 $25 \times 25 \mathrm{~km}$ grid cells (Fig. 1b). Due to the highly dynamic nature of the ice pack, ice concentration and the distance to the ice edge ranged between 0 and $95 \%$ and 0 and $680 \mathrm{~km}$, respectively, for some individual grid cells. The effects of seasonal variability on crabeater seal habitat use and diving behaviour were investigated by dividing data into the breeding and post-breeding seasons. Gender differences in habitat use and diving behaviour were investigated for each of the environmental parameters in each of the seasons. No differences were detected. The overall average dive depth for all seals across both seasons was $12.1 \mathrm{~m}$ $\pm 8.8(\bar{x} \pm \mathrm{SD})$, with a duration of approximately $50 \mathrm{~s}$. Over $85 \%$ of all dives were within 4 to $10 \mathrm{~m}$; $95 \%$ were within $20 \mathrm{~m}$ of the surface.

\section{Seasonal differences in habitat use}

Location data revealed that for the 23 seals tagged, habitat use altered between the breeding and postbreeding seasons. During the breeding season seals generally inhabited areas of deeper water $(\bar{x} \pm$ SD: $3624.5 \pm$ 697.3 vs. $3183.4 \pm 1018.8 \mathrm{~m} ; G_{\mathrm{adj}}=125.42 ; \mathrm{df}=1 ; \mathrm{p}<0.01$; Fig. 2), and areas further from the continental shelf $\left(305.7 \pm 145.3\right.$ vs. $224.1 \pm 167.2 \mathrm{~km} ; G_{\text {adj }}=179.67 ; \mathrm{df}=1$; $\mathrm{p}<0.01$; Fig. 2) than during the post-breeding season. The use of habitat by our 23 seals in the breeding season may not be representative of the entire population because of a bias in capture locations towards the ice edge (for example, Southwell et al. [2005] found crabeater seals in the breeding season were most likely to be present in areas approximately $100 \mathrm{~km}$ north from the continental shelf from a spatially more extensive transect sample, compared with $300 \mathrm{~km}$ for our smaller captured sample). However, the difference between seasons provides an indication of relative use between these times from which inferences about krill distribution might later be made. There was no difference in the ocean floor gradient characteristics between seasons.
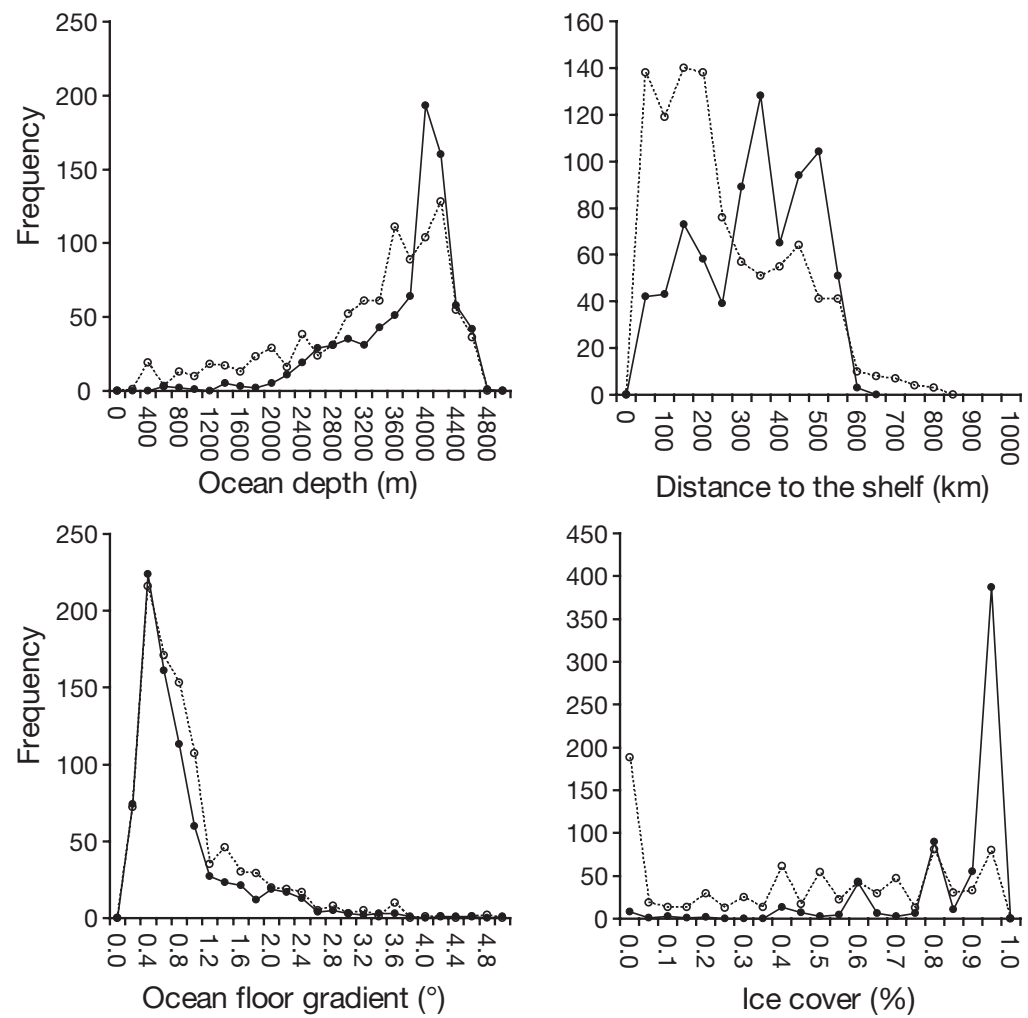

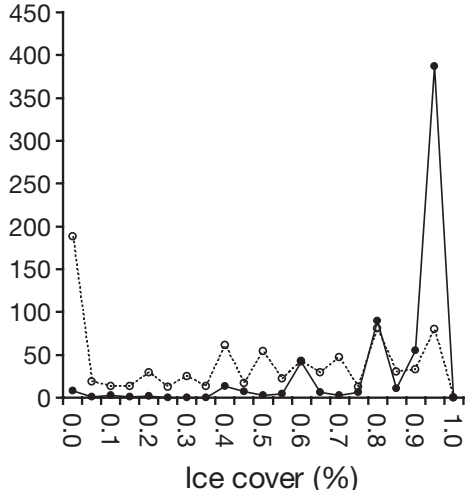

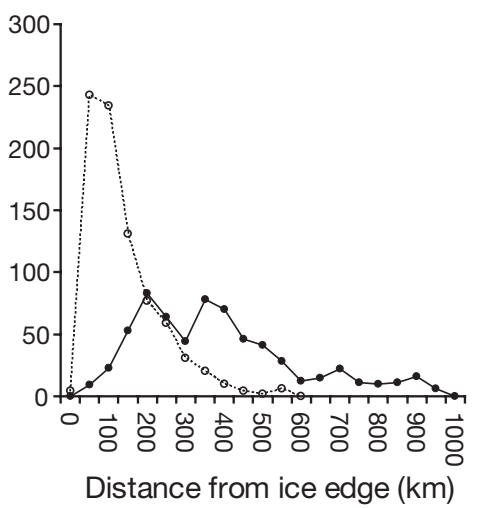

Fig. 2. Lobodon Carcinophaga. Seal frequency distributions in relation to the 5 environmental variables derived from the 23 crabeater seals used to model crabeater seal habitat and behaviour. Frequency counts are the number of grid cells per environmental category. Solid lines represent the breeding season and broken lines represent the postbreeding season 
The dynamic nature of the ice pack required that ice concentration and the distance to the ice edge be calculated weekly and evaluated against the corresponding weekly seal location data. After the breeding season, the seals generally moved south from the heavier ice concentrations inhabited earlier (85 \pm 68 vs. $45 \pm$ $34 \%$ concentration; $G_{\text {adj }}=628.34 ; \mathrm{df}=1 ; \mathrm{p}<0.01$, Fig. 3a) to areas with less ice (Fig. 3b). In the post-breeding season seals also inhabited areas closer to the ice edge $\left(109.7 \pm 94.0\right.$ vs. $358.9 \pm 206.1 \mathrm{~km} ; G_{\mathrm{adj}}=763.27 ; \mathrm{df}=1$; $\mathrm{p}<0.01$ ) than was observed in the breeding season. An important feature to emerge from these results was the use of ice-free regions during the post-breeding season. An analysis of the straight line distances between
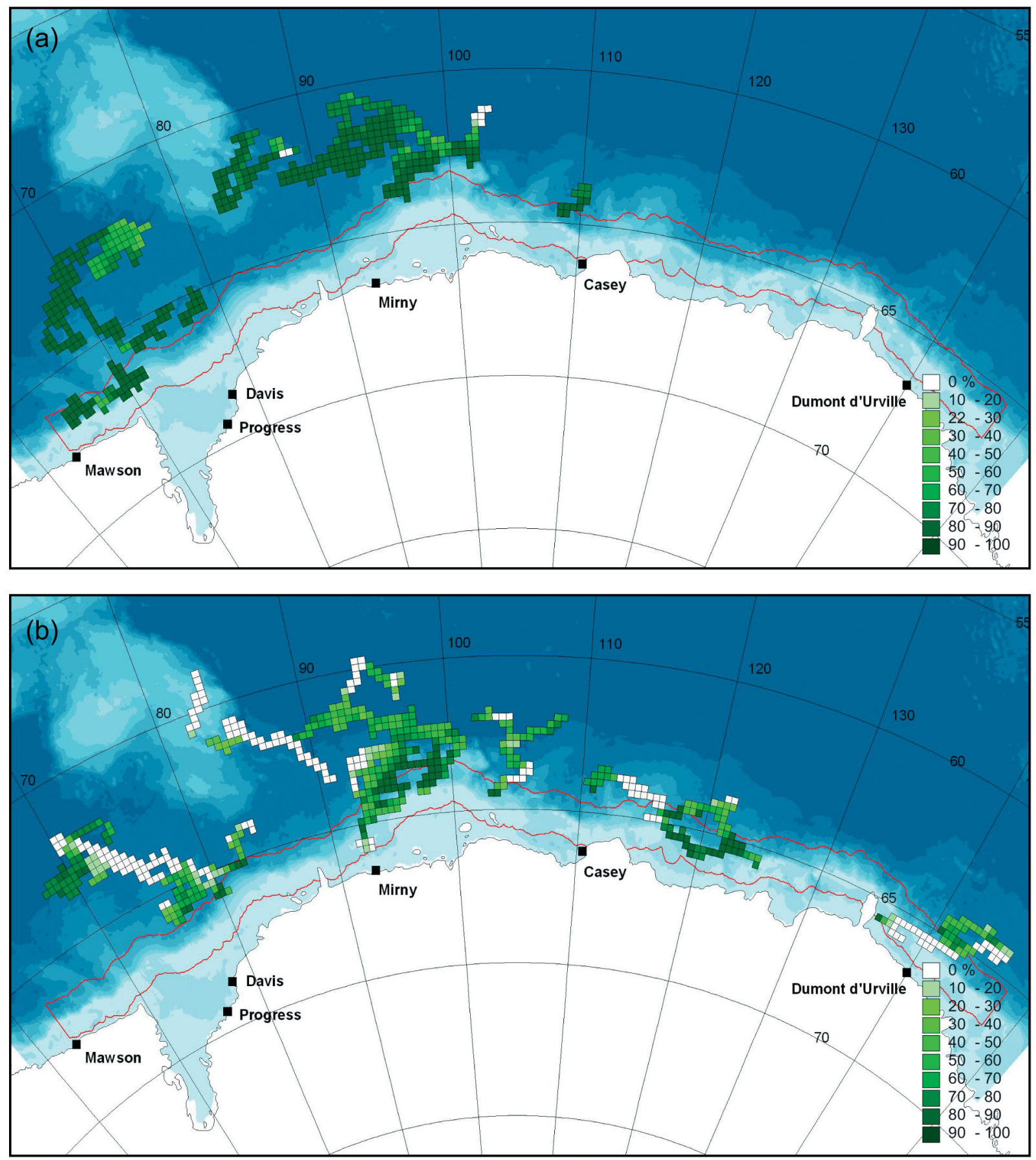

Fig. 3. Lobodon carcinophaga. Mean ice concentration per grid cell for (a) the breeding season and (b) the post-breeding season. Ice concentration is the percentage ice cover, where ' 0 ' represents ice-free zones. The background is bathymetry (m, see Fig. 1a), and the shelf-break zone is outlined in red 
seals and the closest point of the ice pack suggested not only dispersal towards the ice edge during the post-breeding season, but during the post-breeding season $20 \%$ of grid cell occupancy occurred outside the ice pack, which equated to seals spending $14.4 \%$ of the time in open water (Table 3), with some seals more than $100 \mathrm{~km}$ from the ice pack. During the breeding season seals were more closely associated with the pack ice.

\section{Seasonal and spatial differences in diving behaviour}

Diving behaviour differed from the breeding to the post-breeding season $\left(\chi_{\text {rand. }}^{2}=147.8 ; \mathrm{df}=4 ; \mathrm{p}<0.01\right)$, with seals making deeper $(\bar{x} \pm$ SD: $14.1 \pm 11.5$ vs. $8.4 \pm$ $3.4 \mathrm{~m}$ ) dives during the latter season. Diving frequencies within defined depth bins were also different between the breeding and post-breeding seasons $\left(G_{\mathrm{adj}}=5717.6 ; \mathrm{df}=4 ; \mathrm{p}<0.01\right)$, with a greater number of deeper dives post-breeding (Fig. 4a). Diving behaviour differed spatially with significant increases in diving depth and frequency from open water to the shelf break area. Off the shelf break the mean dive depth was $11.9 \pm 9.9 \mathrm{~m}$, whilst over the shelf dive depths averaged $13.3 \pm 8.25 \mathrm{~m}\left(\chi_{\text {rand. }}^{2}=57.9 ; \mathrm{df}=4 ; \mathrm{p}<0.01\right)$. The frequency of dives also varied between the shelf and open water $\left(G_{\mathrm{adj}}=4012.6 ; \mathrm{df}=4 ; \mathrm{p}<0.01\right)$, with greater numbers of shallow dives over the shelf. The number of deeper dives increased away from the shelf (Fig. 4b).

\section{Diurnal variability in diving behaviour}

Diurnal patterns in diving behaviour were compared between seasons and regions. During the breeding season, we found no difference between the day and nighttime average diving depths $(\bar{x} \pm \mathrm{SD}: 8.0 \pm 1.9$ vs. $\left.8.3 \pm 1.9 \mathrm{~m} ; \chi_{\text {rand. }}^{2}=2.2 ; \mathrm{df}=4 ; \mathrm{p}=0.13\right)$. In the post-

Table 3. Lobodon carcinophaga. Percentages of grid cells and time spent in open water at different distances from the ice edge. Progressive distances from the ice pack are inclusive (i.e. $>20$ includes $>50$, etc.). Ice edge was defined as $15 \%$ cover

\begin{tabular}{|lcccc|}
\hline $\begin{array}{l}\text { Distance } \\
(\mathrm{km})\end{array}$ & \multicolumn{2}{c}{ Breeding } & \multicolumn{2}{c|}{ Post-breeding } \\
& $\begin{array}{c}\text { Grid cells } \\
(\%)\end{array}$ & $\begin{array}{c}\text { Time } \\
(\%)\end{array}$ & $\begin{array}{c}\text { Grid cells } \\
(\%)\end{array}$ & $\begin{array}{c}\text { Time } \\
(\%)\end{array}$ \\
\hline$>0$ & 0.8 & 1.1 & 19.5 & 14.4 \\
$>20$ & 0.3 & 0.6 & 14.1 & 10.0 \\
$>50$ & 0.2 & 0.4 & 9.4 & 7.3 \\
$>100$ & 0.0 & 0.0 & 4.6 & 3.3 \\
Totals & 642 & $15067.6(\mathrm{~h})$ & 821 & $15409.4(\mathrm{~h})$ \\
\hline
\end{tabular}
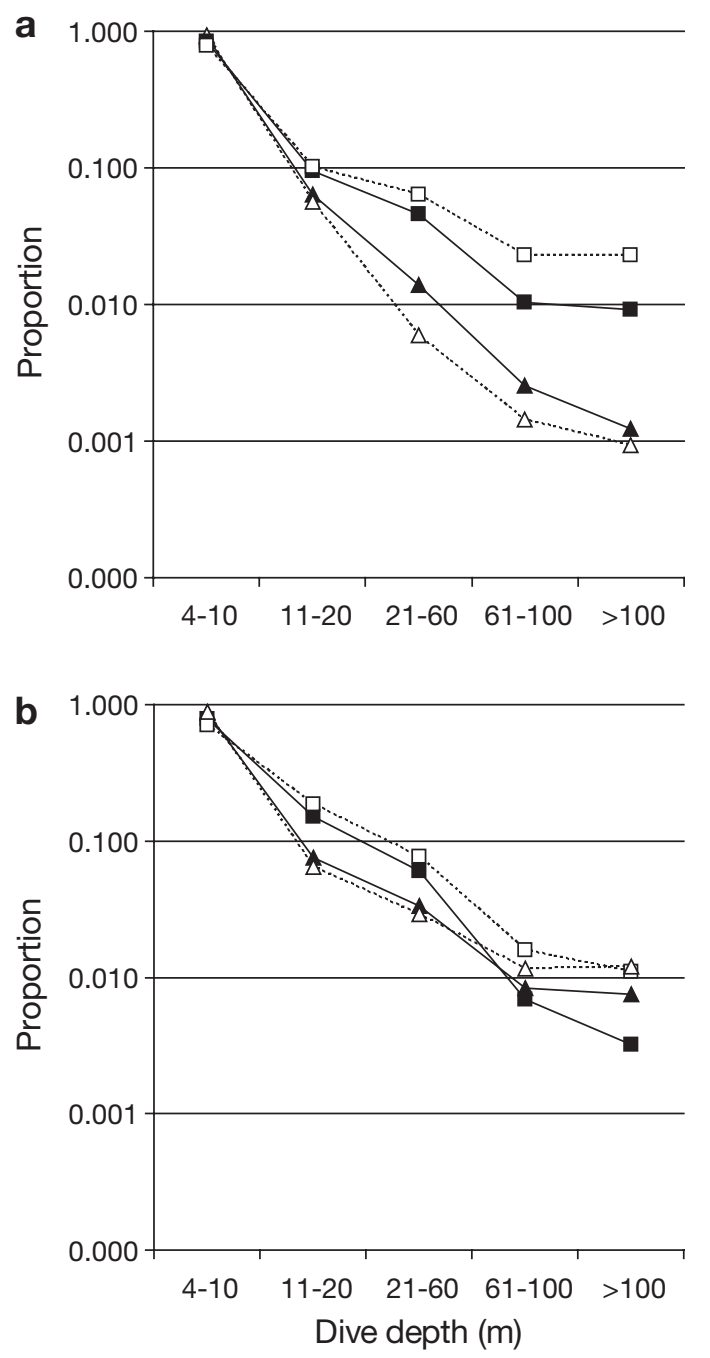

Fig. 4. Lobodon carcinophaga. Proportional frequency of dives within discrete depth bins. (a) Seasonal dive patterns: breeding season diurnal (total no. dives $=14959 ; \cdots \Delta \cdots$ ) and nocturnal dives (total no. dives $=26741 ;-1$ ) , post-breeding season diurnal (total no. dives $=14760 ; \cdots \square \cdots$. dives (total no. dives $=67970 ;-$ ) ; (b) regional dive patterns: off the shelf diurnal (total no. dives $=26308 ; \cdots . \Delta \cdots$ ) and nocturnal dives (total no. dives $=81948 ;-1-$ ), on the shelf diurnal (total no. dives $=3411 ; \cdots \square \cdot(\cdots)$ ) and nocturnal dives (total no. dives $=13018$; $\longrightarrow$ - )

breeding season, however, average dive depths were deeper during the day $(20.0 \pm 21.2$ vs. $12.1 \pm 10.6 \mathrm{~m}$; $\left.\chi_{\text {rand. }}^{2}=17.3 ; \mathrm{df}=4 ; \mathrm{p}<0.01\right)$. Off the shelf, day and nighttime dive depths were different $(\bar{x} \pm$ SD: $14.5 \pm$ 16.3 vs. $10.7 \pm 8.2 \mathrm{~m} ; \chi_{\text {rand. }}^{2}=13.9 ; \mathrm{df}=4 ; \mathrm{p}<0.01$ ); however, no differences were detectable over the shelf $\left(16.3 \pm 25.1\right.$ vs. $\left.12.1 \pm 6.3 \mathrm{~m} ; \chi_{\text {rand. }}^{2}=2.2 ; \mathrm{df}=4 ; \mathrm{p}=0.3\right)$.

Diving frequencies within depth bins clearly illustrated seasonal differences in diel diving behaviour (Fig. 4a). During the breeding season the frequency of dives within all depth bins was greater at night $\left(G_{\mathrm{adj}}=\right.$ 
Table 4. Lobodon carcinophaga. Weights of evidence for each of the 5 variables used to model seal behavioural responses in the breeding and post-breeding seasons. Bold $\Delta w+$ values indicate that variable was included in the model. The percent of deviation indicates the deviance from the null model explained by the inclusion of the model terms

\begin{tabular}{|c|c|c|c|c|c|c|c|}
\hline \multirow{2}{*}{ Season } & \multirow{2}{*}{ Response } & \multirow{2}{*}{$\begin{array}{l}\text { Ocean floor } \\
\text { gradient }\end{array}$} & \multirow[b]{2}{*}{$\begin{array}{l}\text { Ocean } \\
\text { depth }\end{array}$} & \multicolumn{3}{|c|}{ - Variable $\Delta w+$} & \multirow{2}{*}{$\begin{array}{c}\text { Deviance } \\
\text { explained } \\
(\%)\end{array}$} \\
\hline & & & & $\begin{array}{c}\text { Ice } \\
\text { concentration }\end{array}$ & $\begin{array}{l}\text { Distance to } \\
\text { ice edge }\end{array}$ & $\begin{array}{l}\text { Distance to } \\
\text { shelf break }\end{array}$ & \\
\hline \multirow[t]{3}{*}{ Breeding } & Time spent per grid cell & 0.38 & 0.18 & 0.06 & 0.06 & 0.00 & 1.28 \\
\hline & Dive depth & -0.09 & 0.02 & 0.00 & 0.64 & -0.07 & 11.36 \\
\hline & Dive frequency & 0.42 & 0.32 & 0.01 & 0.65 & -0.09 & 10.96 \\
\hline \multirow[t]{3}{*}{ Post-breeding } & Time spent per grid cell & -0.03 & -0.06 & 0.00 & 0.42 & 0.03 & 0.84 \\
\hline & Dive depth & -0.04 & -0.03 & 0.00 & 0.63 & 0.07 & 9.66 \\
\hline & Dive frequency & 0.25 & 0.00 & 0.01 & 0.10 & -0.02 & 0.58 \\
\hline
\end{tabular}

75.6; $\mathrm{df}=4 ; \mathrm{p}<0.01$ ); however, during the post-breeding season there were more deeper dives during the day $\left(G_{\mathrm{adj}}=411.2 ; \mathrm{df}=4 ; \mathrm{p}<0.01\right)$. The distinction between the open water and the shelf was not as discernible (Fig. 4b). Nevertheless, we detected differences in diel diving frequencies on $\left(G_{\mathrm{adj}}=99.5 ; \mathrm{df}=4\right.$; $\mathrm{p}<0.01)$ and off $\left(G_{\mathrm{adj}}=103.6 ; \mathrm{df}=4 ; \mathrm{p}<0.01\right)$ the shelf.

\section{Generalised linear models (GLMs)}

The relationship between the behavioural parameters (time spent per grid cell, dive depth and dive frequency) and variation in the environment was investigated by constructing a set of candidate GLMs for each response. Using full subsets regression of postulated correlates to the response variables, we identified the most-parsimonious combination of correlates explaining variation in each of the response variables (Table 4). During the breeding season there was a positive relationship between the amount of time spent by seals in a given area and ocean depth and ocean floor gradient. Whilst the relationship is weak (\% deviation explained $=1.28 \%$, Table 4 ), the weights of evidence identified these environmental variables as having an important effect on habitat use. In the post-breeding season, distance to the ice edge explained an important, but small amount of the variation in habitat use (\% deviance explained $=0.84 \%$ ). The negative relationship reinforces the conclusions derived from the frequency histograms that seals spend more time nearer the ice edge during the post-breeding season. Example partial residual plots for the relationships identified are shown in Fig. 5.

Environmental correlates generally demonstrated higher explanatory power for the diving behaviour responses (Table 4). Distance to the ice edge emerged as the only variable to affect diving depth in both the breeding and post-breeding seasons. A positive relationship with diving depth was observed during the breeding season, explaining $11 \%$ of the model devia-
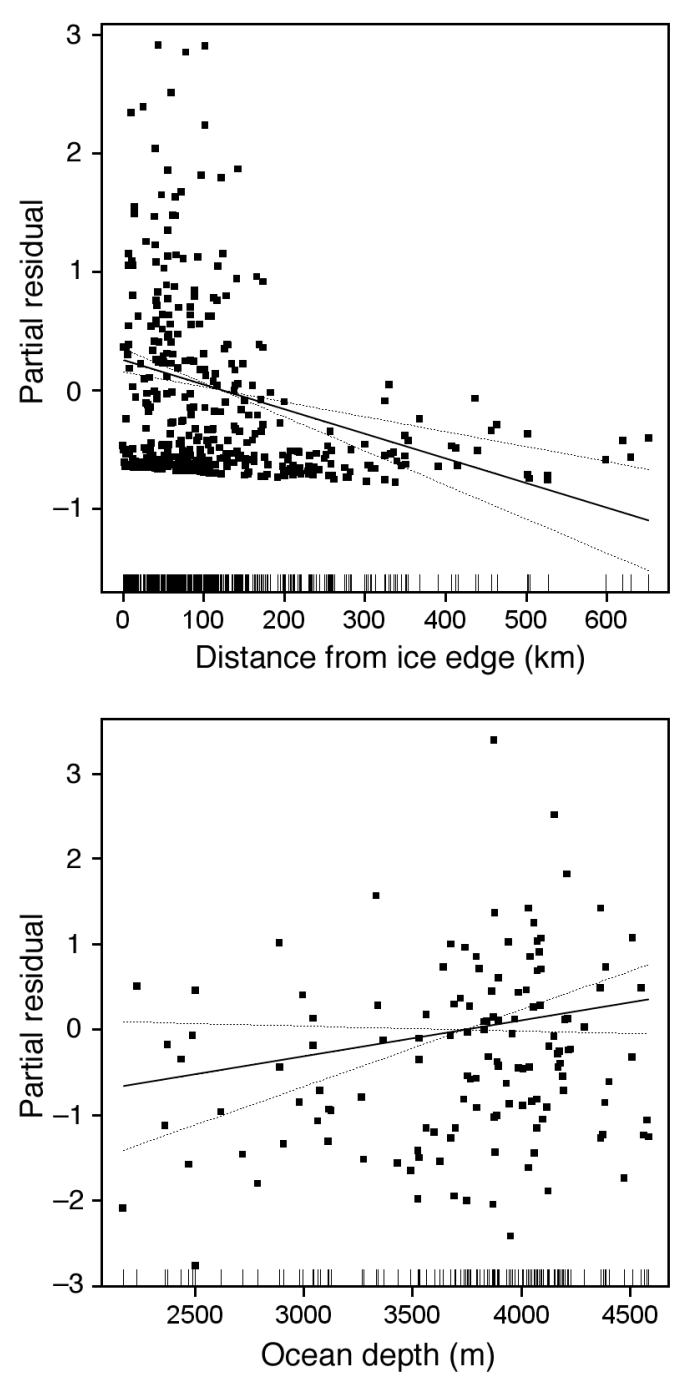

Fig. 5. Lobodon carcinophaga. Examples of the partial residual plots generated from the most-parsimonious generalized linear models relating crabeater seal habitat use and diving behaviour to oceanographic variables. (a) Post-breeding season effect of distance to the ice edge on dive depth (negative) and (b) breeding season effect of ocean depth on diving frequency (positive). Solid lines are the fitted linear models. Dashed lines are approximate $95 \%$ point-wise confidence intervals 
tion, and a negative relationship was observed postbreeding, explaining $10 \%$ of the deviation (Table 4 ). During the breeding season, ocean floor gradient (positive), ocean depth (positive) and distance to the ice edge (positive) were the dominant correlates explaining variation in diving frequency (explaining $11 \%$ of the deviation). A positive relationship with ocean floor gradient was the sole explanatory variable for diving frequency during the post-breeding season (Table 4); however, this was a weak relationship $(0.6 \%$ deviance explained).

\section{DISCUSSION}

Through the integration of geographic location and habitat parameters we have been able to demonstrate that crabeater seal diving behaviour within eastern Antarctic waters varies with seasonal and spatial environmental conditions. In general, the 23 crabeater seals tracked used habitats with high ice concentrations off the continental shelf and over deep water where foraging behaviour was characterised by short, shallow dives (less than $2 \mathrm{~min}$ in duration and $20 \mathrm{~m}$ in depth). Diving activity during the breeding season was constrained by the extended periods spent hauled out by both sexes during lactation (see Southwell 2004 for details). Observed dives were short and shallow; $98 \%$ of all dives were less than $20 \mathrm{~m}$ in depth. Post-breeding behaviour demonstrated an increase in dive frequency and depth; nevertheless, $92 \%$ of dives remained within the top $20 \mathrm{~m}$ of water. Whilst there were clear differences in diving behaviours between the 2 seasons, it is difficult to ascertain the biological significance of these results without further environmental and biological information. However, patterns in diel diving behaviours were clearer between the seasons. No detectable difference was observed between day and nighttime diving during the breeding season. Post-breeding season dives were longer and deeper during the day, switching to increased frequencies of shallower dives during the night. This pattern reflects diel patterns in krill movement (Veit et al. 1993, Boyd et al. 1994, Pauly et al. 2000); krill migrate to the upper water column ( 0 to $50 \mathrm{~m}$ ) during the night and return to deeper water (100 to $200 \mathrm{~m}$ ) during the day (Godlewska \& Klusek 1987, Nordøy et al. 1995). Indeed, Pauly et al. (2000) conducted acoustic surveys for krill off eastern Antarctica in 1996 and found that $58 \%$ of the highest concentrations of krill aggregated within the top $50 \mathrm{~m}$ during the night, and considerable concentrations were common in the top $10 \mathrm{~m}$ (S. Kawaguchi, Australian Antarctic Division, pers. comm.).

In contrast to our findings, Burns et al. (2004) found that crabeater seals off the Antarctic Peninsula during winter (pre-breeding) tended to remain on the shelf and rarely moved to the shelf break or beyond. Seal habitat use in this region was characterised by areas of shallower discontinuous bathymetry and higher sea ice concentrations. Differences found between the Peninsula study and this study may be a result of temporal and geographical differences; nevertheless, during winter crabeater seals on the Peninsula dived for $55 \%$ of the time to depths greater than $50 \mathrm{~m}, 34 \%$ of dives were greater than $100 \mathrm{~m}$, and $47 \%$ of all dives were longer than 5 minutes (Burns et al. 2004). As in the present study, Burns et al. (2004) ascribed seal behaviour as responses to krill availability and suggested seals were exploiting bathymetric configurations conducive to aggregations of krill. Localised, high biomass densities were hypothesised to be associated with a number of sinks and pot-holes in the ocean floor over the continental shelf (Burns et al. 2004). Indeed, Lawson et al. (2004) found that winter distributions of zooplankton biomass were less abundant than summer seasons and most abundant in deep waters close to the bottom.

McMahon et al. (2002) examined the winter distribution of crabeater seals off George V Land, East Antarctica and found that habitat use was characterised by higher ice concentrations over ocean depths less than $1000 \mathrm{~m}$. Although crabeater seals in the McMahon et al. (2002) study were found in deeper waters than those along the Antarctic Peninsula region, seals were still found over the Antarctic shelf, which contrasts with our results in similar regions during spring and summer. Bengston \& Stewart (1992) reported dive and haul-out behaviours of crabeater seals in the Weddell Sea during March 1986. Their findings were similar to those of the present study: $89 \%$ of dives were less than $40 \mathrm{~m}$ deep, and $90 \%$ of all dives were less than $5 \mathrm{~min}$ in duration. Strong diel patterns in diving behaviour with fewer and deeper dives occurring in the day were also reported, and the night period consisted of large numbers of shallower dives (Bengston \& Stewart 1992).

Nordøy et al. (1995) also found these same diving patterns off Queen Maud Land during the austral autumn. Using satellite tags they tracked seal movements from the end of summer through to the start of winter and found that seals had seasonal migrations following the marginal ice zone north through its expansion, then turned south so that by June all seals were deep in the ice-pack. Only on a few occasions were seals observed in water with a depth less than $500 \mathrm{~m}$, and by late April/May all seals were present in areas of ocean depth around 3000 to 5000 m (Nordøy et al. 1995). These authors further illustrated that crabeater seal diving behaviour varied seasonally. Seals made a greater number of deeper dives in February (70\% of all dives were less than $52 \mathrm{~m}$ deep), reduc- 
ing deep diving as they entered June, when $96 \%$ of all dives were less than $52 \mathrm{~m}$.

The present study further illustrates seasonal variability in crabeater seal behaviour. Observed seals spent the breeding season in areas with heavy ice concentrations over deep water, which is congruent with this species' selection of stable ice substrata during the pupping and mating season (Southwell et al. 2003). Crabeater seals form breeding groups (Siniff et al. 1979) in the breeding season, generally consisting of a male and female (with or without a pup) pair, which spend large proportions of the time hauled out on ice floes with little to no foraging (Southwell 2004). Although the present sample was dominated by male seals, the importance of stable ice floes extends to the female component of the population. Both females and males haul out for extended periods during the breeding season (see Southwell 2004). It is expected, therefore, that both sexes would be energetically depleted at the end of the pupping season and should hence disperse to areas where prey availability might be higher in the post-breeding season. These included areas associated with the ice edge, areas with more-complex ocean floor topography and areas toward the continental shelf. However, the weak explanatory power of the models considered suggests that ice conditions themselves only marginally explained the variation in dive behaviour. What is evident from this and previous studies of crabeater seals is the seasonal and geographically variable nature of diving behaviours. With the exception of the breeding season when seals are hauled out, most studies agree that crabeater seal behaviour is linked to the behaviour of their predominant prey species, krill. We believe that our results suggest crabeater seal behaviour is partially a function of ice characteristics within the breeding season, and food (krill) availability during the non-breeding season.

Habitat use studies using tracked seals have demonstrated that seals migrate geographically during nonbreeding periods to areas with higher predictability of locating krill such as the shelf break and the marginal ice zone. Our attempts to use oceanographic variables to develop models of crabeater seal behaviour demonstrated limitations in inferring behaviour from a simple set of environmental factors. We identified certain factors (i.e. ocean depth, distance to the ice edge, distance to the shelf break and ocean floor gradient) that had seasonal effects on diving behaviour, although these correlates explained only a small component of the variation in the response variables tested. Similar attempts to model crabeater seal distribution based on transect data (Southwell et al. 2005) also reported low predictive power, although ocean depth was again identified as an influential factor on crabeater seal dis- tribution in the breeding season. During this study (Southwell et al. 2005), the distance to the ice edge emerged as the dominant factor influencing seal behaviour and habitat use. Limitations in our ability to infer seal behaviour from a suite of plausible environmental correlates implies an over-simplification of the environment influencing seal distribution and behaviour in this region. Species-habitat models often belie the ecological complexity of species' relationships with their environment simply because all the variables cannot be recorded, or interactions are too complex to quantify satisfactorily. Whilst our understanding of the influences driving crabeater seal distribution has improved as a result of telemetry studies, it would appear premature to infer cross-species patterns in distribution and abundance with krill given the low predictive power of models derived from such data.

The present study encompasses data over a large spatial range (between $63^{\circ} \mathrm{E}$ and $147^{\circ} \mathrm{E}$, extending from the continent north to $58^{\circ} \mathrm{S}$ ) collected over multiple years. As a result, the data are confounded by inter-annual variability in ice characteristics, oceanographic variability and subsequent biological variability. Information on simultaneous oceanographic variability was unavailable for inclusion in our models. Variation in sea ice characteristics was included with respect to crabeater seal movements and behaviour by interpolating weekly ice maps; however, the flow-on effect of ice characteristics on ocean productivity (in particular, krill) was beyond the scope of this paper. Little information is available on krill distribution and abundance in eastern Antarctica, the only coinciding spatial information on krill being the BROKE (baseline research on oceanography, krill and the environment, 1996) (Pauly et al. 2000) and FIBEX (first international BIOMASS experiment, 1981) (Trathan et al. 1992) large-scale surveys (but with limited temporal overlap). What is clearly evident from these and other surveys is that krill distribution and abundance vary considerably from region to region and year to year (Siegel 2005). No clear relationships between the hypothesised factors influencing large-scale krill distribution and abundance have been demonstrated (Siegel 2005). Local variability is most likely a result of behavioural responses to factors such as food availability and predator avoidance. Despite not identifying strong relationships between crabeater seals and a selection of environmental correlates, we have identified some relationships and patterns that illustrate linkages between seals, their environment and their key prey.

We made an important discovery, namely that crabeater seals were not always associated with the pack ice, and Burns et al. (2004) also noted that crabeater seals, at times, used areas of open water. We found that during the post-breeding season, $20 \%$ of the geo- 
graphical range $(14 \%$ of the total time seals were tracked) was spent in open water, whereas earlier descriptions of crabeater seal distribution confined the species to the pack ice zone (Erickson et al. 1971, Condy 1977, Bengston \& Stewart 1992, Nordøy et al. 1995). Our findings suggest that this is not always the case, even despite our classification of open water $(>15 \%$ ice cover). Indeed, the weak correlation of crabeater seal distribution with sea ice cover in this and Southwell et al. (2005) study, even during the breeding season, suggests that open-water habitat may be more important than previously thought. The dynamic and regionally variable use of pelagic habitats by this widely abundant Antarctic predator has important implications for the estimation of crabeater seal abundance. Considerable sampling of this species' distribution, diving behaviour and habitat selection across a wide range of habitat complexes has revealed area- and seasonally specific trends. These must be taken into account when corrections are applied to any regional estimates of biomass.

Acknowledgements. We thank Iain Field and Mike Sumner for analytical assistance and helpful suggestions. Two anonymous reviewers provided helpful comments to improve the manuscript. We also thank the people involved with the Australian Antarctic Division's APIS program, along with the many people involved in the cruises assisting in the deployment of satellite tags.

\section{LITERATURE CITED}

Agnew D (1997) Review: the CCAMLR Ecosystem Monitoring Program. Ant Sci 9:235-242

Alonzo SH, Switzer PV, Mangel M (2003) An ecosystembased approach to management: using individual behaviour to predict the indirect effects of Antarctic krill fisheries on penguin foraging. J Appl Ecol 40:692-702

APIS (1996) APIS Survey Design and Implementation Workshop. APIS report no. 2, Scientific Committee on Antarctic Research, Cambridge

Bengston JL (2002) Crabeater seal. In: Perrin WF, Wursig B, Thewissen JGM (eds) Encyclopedia of marine mammals. Academic Press, San Diego, CA, p 302-304

Bengston JL, Stewart BS (1992) Diving and haulout behaviour of crabeater seals in the Weddell Sea, Antarctica, during March 1986. Polar Biol 12:635-644

Boyd IL, Arnould JP, Barton T, Croxall JP (1994) Foraging behaviour of Antarctic fur seals during periods of contracting prey abundance. J Anim Ecol 63:703-713

Bradshaw CJA, Hindell MA, Michael KJ, Sumner M (2002) The optimal spatial scale for the analysis of elephant seal foraging as determined by geo-location in relation to sea surface temperatures. ICES J Mar Sci 59:770-781

Burnham KP, Anderson DR (2002) Model selection and inference: a practical information-theoretic approach. SpringerVerlag, New York

Burns JM, Costa DP, Fedak MA, Hindell MA and 5 others (2004) Winter habitat use and foraging behavior of crabeater seals along the Western Antarctic Peninsula. Deep-Sea Res II 51:2279-2303
Clarke J, Kerry K, Irvine L, Phillips B (2002) Chick provisioning and breeding success of Adelie penguins at Bechervaise Island over 8 successive seasons. Polar Biol 25:21-30

Condy PR (1977) Results of the 4th seal survey in the KingHaakon-Vii Sea Antarctica. S Afr J Antarct Res:10-13

Constable AJ, Nicol S, Strutton PG (2003) Southern Ocean productivity in relation to spatial and temporal variation in the physical environment. J Geophys Res 108:6-1 to 6-21

Croxall JP, Reid K, Prince PA (1999) Diet, provisioning and productivity responses of marine predators to differences in availability of Antarctic krill. Mar Ecol Prog Ser 177: 115-131

Erickson AW, Siniff DB, Cline DR (1971) Distributional ecology of antarctic ice seals. In: Deacon G (ed) Symposium on Antarctic ice and water masses. SCAR, Cambridge, p 55-76

Godlewska M, Klusek Z (1987) Vertical distribution and diurnal migrations of krill-Euphausia superba Dana-from hydroacoustical observations, SIBEX, December 1983/ January 1984. Polar Biol 8:17-22

Hewitt R, Lipsky J (2002) Krill. In: Perrin WF, Wursig B, Thewissen JGM (eds) Encyclopedia of marine mammals. Academic Press, San Diego, CA, p 676-684

Hindell MA, Bradshaw CJA, Harcourt RG, Guinet C (2003) Ecosystem monitoring: are seals a potential tool for monitoring change in marine systems? In: Gales NJ, Hindell MA, Kirkwood R (eds) Marine mammals. Fisheries, Tourism and Management Issues, Chapter 17. CSIRO Publishing, Melbourne, p 330-343

Lawson GL, Wiebe PH, Ashjian CJ, Gallager SM, Davis CS, Warren JD (2004) Acoustically-inferred zooplankton distribution in relation to hydrography west of the Antarctic Peninsula. Deep-Sea Res II 51:2041-2072

Lebreton JD, Burnham KP, Clobert J, Anderson DR (1992) Modeling survival and testing biological hypotheses using marked animals: a unified approach with case studies. Ecol Monogr 62:67-118

Lynnes AS, Reid K, Croxall JP (2004) Diet and reproductive success of Adelie and chinstrap penguins: linking response of predators to prey population dynamics. Polar Biol 27:544-554

McCafferty DJ, Boyd IL, Walker TR, Taylor RI (1998) Foraging responses of Antarctic fur seals to changes in the marine environment. Mar Ecol Prog Ser 166:285-299

McCullagh P, Nelder JA (1989) Generalised linear models. Chapman \& Hall, London

McMahon C, Hindell M, Dorr T, Massom RA (2002) Winter distribution and abundance of crabeater seals off George V Land, East Antarctica. Ant Sci 14:128-133

NOAA National Geophysical Data Centre (2001) ETOPO2 Global 2 minute gridded topography \& bathymetry. National Geophysical Data Center, Boulder, CO

Nordøy ES, Folkow L, Blix AS (1995) Distribution and diving behaviour of crabeater seals (Lobodon carcinophagus) off Queen Maud Land. Polar Biol 15:261-268

Pauly T, Nicol S, Higginbottom I, Hosie G, Kitchner J (2000) Distribution and abundance of Antarctic krill (Euphausia superba) off East Antarctica $\left(80-150^{\circ} \mathrm{E}\right)$ during the austral summer of 1995/1996. Deep-Sea Res II 47:2465-2488

R Development Core Team (2004) R: A language and environment for statistical computing. Vienna, Austria. Available at: www.R-project.org

Riedman M (1990) The pinnepeds: seals, sea lions, and walruses. University Press, Berkeley, CA

Roff D, Bentzen P (1989) The statistical analysis of mitochondrial DNA polymorphisms: $\mathrm{chi}^{2}$ and the problem of small samples. Mol Biol Evol 6:539-545 
Service Argos (1996) User's Manual. Argos/CSL, Landover, MD

Shaughnessy PD (1999) The action plan for Australian seals. Environment Australia, Canberra

Siegel V (2005) Distribution and population dynamics of Euphausia superba: summary of recent findings. Polar Biol 29:1-22

Siniff DB, Stirling I, Bengtson JL, Reichle RA (1979) Social and reproductive behaviour of crabeater seals (Lobodon carcinphagus) during the austral spring. Can J Zool 57: 2243-2255

Smith WHF, Sandwell DT (1997) Global sea floor topography from satellite altimetry and ship depth soundings. Science 277:1956-1962

Sokal RR, Rohlf FJ (1995) Biometry: the principles and practice of statistics in biological research. W. H. Freeman, New York

Southwell C (2004) Satellite-linked dive recorders provide insights into the reproductive strategies of crabeater seals (Lobodon carcinophagus). J Zool 264:399-402

Southwell C, Kerry K, Ensor P, Woehler EJ, Rogers T (2003) The timing of pupping by pack-ice seals in East Antarctica. Polar Biol 26:648-652

Editorial responsibility: Otto Kinne (Editor-in-Chief), Oldendorf/Luhe, Germany
Southwell C (2005) Optimising the timing of visual surveys of crabeater seal abundance: haulout behaviour as a consideration. Wildl Res 32(4):333-338

Southwell CJ, Kerry KR, Ensor PH (2005) Predicting the distribution of crabeater seals Lobodon carcinophaga off east Antarctica during the breeding season. Mar Ecol Prog Ser 299:297-309

Thompson D, Hiby AR, Fedak MA (1993) How fast should I swim? Behavioural implications of diving physiology. Zool Symp No. 66, p 349-367

Trathan PN, Agnew DJ, Miller DGM, Watkins JL and 5 others (1992) Krill biomass in Area 48 and Area 58: Recalculation of FIBEX data, in Selected Scientific Papers (SC-CAMLRSSP/9), CCAMLR, Hobart, p 157-181

Veit RR, Silverman ED, Everson I (1993) Aggregation patterns of pelagic predators and their principal prey, Antarctic krill, near South Georgia. J Anim Ecol 62:551-564

Vincent C, McConnell BJ, Ridoux V, Fedak MA (2002) Assessment of Argos location accuracy from satellite tags deployed on captive gray seals. Mar Mamm Sci 18:156-166

Wildlife Computers (1995) SDR: Satellite-linked time depth recorder. Wildlife Computers, Redmond, VA

Submitted: December 30, 2005; Accepted: May 27, 2006

Proofs received from author(s): April 3, 2007 